\title{
Climate Change Awareness and Adaptation Strategy in Ibadan Metropolis, Nigeria
}

\author{
Okuwa Oluwakemi Bolaji \\ Nigeria Institute of Social and Economic Research Ojoo, Ibadan, Nigeria
}

\begin{abstract}
Discovery of renewable energy as an alternative means of generating power without depleting the ozone layer or doubling $\mathrm{Co}_{2}$ in the ecosphere is crucial in managing climate change risks. This study explains the awareness of the people in Ibadan metropolis about the adverse effect of climate change. 300 questionnaires were administered using random sampling technique in six communities drawn from four local governments out of nine in Ibadan metropolis in Oyo state. Descriptive statistics and Chi-square estimation technique were used to analyze the data. The result reveals that both urban and rural respondents have knowledge of climate change and renewable energy. Respondents' knowledge about climate change highlighted teaching from school. Also, rural respondents are willing to pay for renewable energy as an adaptation strategy to minimize the effect of climate change caused by carbon emissions and environmental pollution. The study, therefore, concludes that renewable energy should be introduced as an alternative source of energy at a minimal cost.
\end{abstract}

Keywords: Climate Change, Renewable Energy, Knowledge, Awareness, Carbon footprint, Adaptation.

DOI: $10.7176 / \mathrm{JRDM} / 69-05$

Publication date:October $31^{\text {st }} 2020$

\section{Introduction}

Education and training are part of the elements used over the years to drive human capital development. This can take the form of raising awareness, transferring knowledge, and skills training. Knowledge about changes in the environment is critical in achieving human and sustainable development. Climate change has emerged as a subject of concern in the past few years as scientists have become increasingly concerned about the greenhouse effect (Jain 1993). Changes in the climate are not unexpected this is expected to affects the frequency and intensity of the hazards and the probability of extreme events (for instance those linked to sea-level rise, extreme heat and ozone depletion). It is a major threat to people's health and has implication for sustainable development in Africa. Several pieces of evidence of climate change that are due to human activity have been collected for many years since the industrial revolution. According to IPCC, (2007) the Global Greenhouse Gas emission that has been due to human activities increased immediately after the industrial times. Specifically, the increase of $70 \%$ between 1970 and 2004 was reported by IPCC, (2007). Consequences of higher average temperatures due to the greenhouse effect such as rises in sea level, desertification, extinction of plant and animal species, shifting of agricultural patterns and increased frequencies in extreme weather phenomena such as cyclones are now considered unequivocal evidence by the scientific community (IPCC, 2007, 2014) with very few divergent views (Khilyuk and Chilingar, 2003).

Therefore, awareness of the adverse effect of climate change and the need to embrace other sources of energy especially renewable energy and proper waste management is very crucial in managing the risk of climate change and mitigating the carbon footprint. This study utilized structured questionnaires to generate information from the respondents (workers and students) about their knowledge and understanding of climate change risk and adaptation to renewable energy and proper waste management as a way of mitigating their carbon footprint. In exception of the introductory section, the paper contains four sections. The first is a review of the literature on climate change and renewable energy. The second describes the method of estimations adopted for the study. In the third section, the paper presented the empirical results and findings while the last section contains the concluding remark.

\section{Literature Review}

The state of knowledge as regards awareness and adaptation of climate change is presented in this subsection. We start with Shahid and Piracha (2016), who analyzed the awareness of Climate Change and its impacts and adaptation at Local Level in Punjab, Pakistan. The results showed that the local officials at union councils possess a low level of education and are poorly trained. They, however, do not know about international climate change agreements. They also found that the local officials are not adequately equipped to mitigate the effects of climate change. De Sousa et al. (2018) examined the farmers' climate awareness and their perceptions regarding the change in climate patterns as well as their choices of farming practices to adapt to these changes. The study indicated that reforestation was the preferred adaptation strategy among interviewed farmers and that educational profiles and the size of landholdings drive the adoption of this and other practices. The findings provided evidence to support the design of capacity development interventions targeting specific groups of farmers according to their main crop and education profile. Ahmad et al., (2019) analysed the adaptation towards climate change among islanders in 
Malaysia. Using a total of 400 islanders were used as the respondents through a multi-stage sampling technique. They found a moderate to high mean score for adaptation aspects namely awareness, dependency and structure.

Ole, et al (2009) examined the perception of climate change and the strategies for coping and adaptation by sedentary farmers in the savanna zone of central Senegal using focus group discussion and household survey. They found that households are aware of climate variability and identified wind and occasional excess rainfall as the most destructive climate factors. Households also attributed poor livestock health, reduced crop yields and a range of other problems to climate factors especially wind. Bostrum, et al (1994) examined public understanding of climate change using a set of exploratory studies and mental models, they found that automobile use, heat, and emissions from industrial processes, aerosol spray cans and pollution, in general, were frequently perceived as primary causes of global warming. Also, the "greenhouse effect" was often interpreted literally as the cause of a hot and steamy climate. The issue of misconception about the meaning of climate change necessitates the need to create awareness and knowledge of climate change among the citizenry.

\section{Methodology}

Global development agenda in the past and the present Sustainable Development Goals (SDG) rely on education as a means towards their achievement, the main elements that comprise this means are skills training, transferring knowledge and raising awareness among individuals, institutions, regional and national government. Hence empowering them to act as an active agent for sustainable human development. The theoretical underpinning of this study is hinged on the theory of human development that emphasized education, skills and knowledge in achieving economic growth and development. The methodological approach to this study relies on the use of structured questionnaires to generate information from the respondents about their knowledge and understanding of climate change risk and adaptation to renewable energy as a way of mitigating their carbon footprint. The study utilizes random sampling techniques to administered 300 questionnaires in six communities drawn from five local governments out of nine in Ibadan metropolis in Oyo state. 3 rural communities (Eruwa, Iyana Church, Idi ayunre) and 3 urban communities (Bodija, Akobo Orogun) were selected. Descriptive statistics and Chi-square estimation technique were used to analyze the data. The choice of these communities is to show whether the urban settlers are more informed than the rural settlers. The questionnaires covered mainly information about the socialeconomic profile of the respondents, availability of renewable energy and waste management in their communities (carbon footprint), understanding of climate change and their effort in militating against carbon footprint by adapting to renewable energy and proper waste management.

\section{Results and Discussions}

\subsection{Knowledge about climate change}

This section discusses the respondents' knowledge of climate change using chi-square tests of independence and their significance. The first question that the respondents were asked about their knowledge of climate change is if they have heard of climate change. Over 90.6 and 80.8 per cent of the respondents (urban and rural respectively) say "yes". This shows that respondents have information about climate change. A larger percentage of urban (55.2 per cent) believed that climate change is caused by heavy rainfall while about 25 per cent believed that all options (greenhouse gas, heat waves, ozone depletion, heavy rainfall, rising temperature/sea level) were the causes of climate change. However, 13 per cent of the rural think climate change is caused by ozone depletion; this is followed by all option 29.6 per cent and 66.4 per cent heavy rainfall. The main greenhouse gas according to all respondents is carbon dioxide (with urban 61.4 per cent and rural 73.3 per cent) this is followed by Nitrogen ( 24.3 per cent for urban and 11.9 per cent for rural). The respondents were also asked about their understanding of the effect of a warmer climate on sea level, rainfall, sunshine and farmers crops. A larger percentage of the respondents believed that the sea level will rise (57.9 per cent urban and 54.5 per cent rural) while over 27 per cent and 16.8 per cent believed it will fall. The urban settlers understanding of the effect of a warmer climate on rainfall shows that rainfall will be lower in some places and higher in some places $(29.3 \%)$ while 51.5 per cent of rural believed it will be higher in most places. Most of the respondents (an average of over 40 per cent) think that a warmer climate will bring more sunshine in most places and affect the crops of farmers badly. A chi-square test applied to the data as revealed in table 1 shows insufficient evidence to reject the null hypothesis that rural and urban respondents have knowledge about climate change and that their responses are independent of each other. The pvalue ranges between 0.05 and 0.01 . 
Table 1. Urban and Rural Knowledge About Climate Change

\begin{tabular}{|c|c|c|c|c|c|}
\hline Variables/Questions & Response Categories & $\begin{array}{l}\text { Urban } \\
\text { (\%) }\end{array}$ & $\begin{array}{l}\text { Rural } \\
\text { (\%) }\end{array}$ & $\begin{array}{l}\text { Pearson's } \\
\text { Chi }\end{array}$ & $\begin{array}{l}\text { P- } \\
\text { value }\end{array}$ \\
\hline \multirow{2}{*}{$\begin{array}{l}\text { Have you heard about climate } \\
\text { change? }\end{array}$} & Yes & 96.6 & 80.8 & \multirow[t]{2}{*}{0.374} & \multirow[t]{2}{*}{0.05} \\
\hline & No & 3.4 & 19.2 & & \\
\hline \multirow{6}{*}{$\begin{array}{l}\text { What do you think is the cause } \\
\text { of Climate Change? }\end{array}$} & Greenhouse gases & 15.2 & 9.6 & \multirow{6}{*}{0.019} & \multirow{6}{*}{0.01} \\
\hline & Heatwaves & 2.1 & 1.6 & & \\
\hline & Ozone Depletion & 20.7 & 10.4 & & \\
\hline & Heavy Rainfall & 55.2 & 66.4 & & \\
\hline & Rising temperature /Sea level & 8.3 & 8.0 & & \\
\hline & All of the above & 17.2 & 29.6 & & \\
\hline \multirow{3}{*}{$\begin{array}{l}\text { Which of the following do you } \\
\text { think is the main greenhouse } \\
\text { gas? }\end{array}$} & Oxygen & 14.3 & 16.8 & \multirow[t]{3}{*}{0.158} & \multirow[t]{3}{*}{0.05} \\
\hline & Carbon dioxide & 61.4 & 73.3 & & \\
\hline & Nitrogen & 24.3 & 11.9 & & \\
\hline \multicolumn{6}{|l|}{$\begin{array}{l}\text { What do you think the effect of } \\
\text { a warmer climate will be? }\end{array}$} \\
\hline \multirow{4}{*}{ Sea level will... } & Rise & 57.9 & 54.5 & \multirow{4}{*}{0.550} & \multirow{4}{*}{0.01} \\
\hline & Fall & 27.1 & 16.8 & & \\
\hline & Stay the same & 6.4 & 9.9 & & \\
\hline & Don't know & 8.6 & 18.8 & & \\
\hline \multirow{5}{*}{ Rainfall will be... } & Higher in most places & 51.4 & 51.5 & \multirow{5}{*}{0.236} & \multirow{5}{*}{0.01} \\
\hline & Lower in most & 10.0 & 10.9 & & \\
\hline & $\begin{array}{l}\text { Lower in some places \& higher } \\
\text { in some }\end{array}$ & 29.3 & 18.8 & & \\
\hline & The same in most places & 7.9 & 12.9 & & \\
\hline & Don't know & 1.4 & 5.9 & & \\
\hline \multirow{5}{*}{ Sunshine } & More Sunshine in most places & 47.1 & 56.4 & \multirow{5}{*}{0.137} & \multirow{5}{*}{0.01} \\
\hline & Less sunshine in most places & 5.0 & 8.9 & & \\
\hline & $\begin{array}{l}\text { Less in some places and more in } \\
\text { others }\end{array}$ & 32.9 & 19.8 & & \\
\hline & The same in most places & 9.3 & 11.9 & & \\
\hline & Don't know & 5.7 & 2.9 & & \\
\hline
\end{tabular}

\section{Source: Climate Change Survey 2015}

\subsection{Sources of Climate Change Knowledge}

Information about climate change is very important to the way people can mitigate and adapt to climate change risk. This can occur through awareness and education. Table 2 shows the source of respondents' knowledge about climate change; it reveals that over 35 per cent of the respondents learn about climate change in school followed by radio (40.9 per cent for rural and 27.1 per cent); television ( 15.7 per cent) for urban and 7.9 per cent; book and magazine (11.9 per cent) for rural and 12.9 per cent for urban. The Internet also played an important role as the source of knowledge about climate change, 6.4 per cent and 1.9 per cent for urban and rural respectively.

Table 2. Sources of climate change knowledge

\begin{tabular}{|c|c|c|c|c|c|c|c|}
\hline \multirow[b]{2}{*}{ Question } & \multirow[b]{2}{*}{ Response Categories } & \multicolumn{2}{|c|}{ Urban } & \multicolumn{2}{|c|}{ Rural } & \multirow[t]{2}{*}{ Pearson's chi } & \multirow[t]{2}{*}{ P-value } \\
\hline & & Number & $\%$ & Number & $\%$ & & \\
\hline \multirow{8}{*}{$\begin{array}{l}\text { Sources of } \\
\text { Climate change } \\
\text { Knowledge. }\end{array}$} & Taught in school & 49 & $35.0 \%$ & 32 & $31.7 \%$ & \multirow{8}{*}{0.641} & \multirow{8}{*}{0.05} \\
\hline & Parents & 0 & $.0 \%$ & 0 & $.0 \%$ & & \\
\hline & TV & 22 & $15.7 \%$ & 8 & $7.9 \%$ & & \\
\hline & Radio & 38 & $27.1 \%$ & 40 & $39.6 \%$ & & \\
\hline & Book/Magazine & 11 & $7.9 \%$ & 12 & $11.9 \%$ & & \\
\hline & Talking to friends & 6 & $4.3 \%$ & 3 & $2.9 \%$ & & \\
\hline & Internet & 9 & $6.4 \%$ & 5 & $4.9 \%$ & & \\
\hline & Others & 5 & $3.6 \%$ & 1 & $0.9 \%$ & & \\
\hline
\end{tabular}

Source: Climate Change Survey 2015

4.3. Carbon Foot Print Knowledge

Carbon footprint is historically defined as the total sets of greenhouse gas emissions caused by an organization, 
event, product or person. The single largest source of emissions for the typical household is from driving (gasoline use). Transportation as a whole (driving, flying \& small amount from public transit) is the largest overall category, followed by housing (electricity, natural gas, waste, construction) food (mostly from red meat, dairy and seafood products, but also includes emissions from all other food) and services. It is often expressed in terms of the amount of dioxide, or its equivalent of other GHGs, emitted. The way household handles their waste in the family will determine how they will manage climate change risk caused by carbon footprint. The most frequently used method of waste disposal identified by the respondents is government-designated refuse dumps with 43.6 and 44.6 per cent responses from the urban and rural respectively. This is followed by burning in open space (18.9 per cent for urban and 22.8 per cent for rural. Collection by waste management firm recorded 15 per cent for urban settlers and 14.9 per cent for rural. Dumping in open space is also identified by the respondents as one of the most frequent waste disposal methods in the communities. To the urban settlers, the most important challenge associated with the waste collection was "Ignorance of the people on benefits of good waste management behaviour" with 27.9 per cent while rural identified "Lack of government-designated waste dumps/skips" as the major challenge (30.1\%). Table 3. Knowledge of Carbon Foot Print (Waste)

\begin{tabular}{|c|c|c|c|c|c|c|c|}
\hline \multirow[b]{2}{*}{ Questions } & \multirow{2}{*}{ Response Categories } & \multicolumn{2}{|c|}{ Urban } & \multicolumn{2}{|c|}{ Rural } & \multirow[t]{2}{*}{$\begin{array}{c}\text { Pearson } \\
\text { Chi }\end{array}$} & \multirow{2}{*}{$\begin{array}{c}\text { P-Value } \\
\%\end{array}$} \\
\hline & & Number & $\%$ & Number & $\%$ & & \\
\hline \multirow{6}{*}{$\begin{array}{l}\text { Which waste } \\
\text { disposal } \\
\text { method do } \\
\text { you most } \\
\text { frequently } \\
\text { use? }\end{array}$} & Burning in open space & 26 & $18.6 \%$ & 23 & $22.8 \%$ & \multirow{6}{*}{0.495} & \multirow{6}{*}{0.05} \\
\hline & Incineration & 20 & $14.3 \%$ & 7 & $6.9 \%$ & & \\
\hline & $\begin{array}{l}\text { Open dumping } \\
\text { (drainages, } \\
\text { available space) }\end{array}$ & 12 & $8.6 \%$ & 11 & $10.9 \%$ & & \\
\hline & $\begin{array}{l}\text { Government designated } \\
\text { refuse dumps }\end{array}$ & 61 & $43.6 \%$ & 45 & $44.6 \%$ & & \\
\hline & $\begin{array}{l}\text { Collection by a waste } \\
\text { collection firm }\end{array}$ & 21 & $15.0 \%$ & 15 & $14.9 \%$ & & \\
\hline & Others & 0 & $.0 \%$ & 0 & $.0 \%$ & & \\
\hline \multirow{7}{*}{$\begin{array}{l}\text { How often is } \\
\text { your waste } \\
\text { collected from } \\
\text { your primary } \\
\text { residence or } \\
\text { from } \\
\text { containers } \\
\text { where you } \\
\text { dispose of } \\
\text { your waste? }\end{array}$} & Irregular collection & 11 & $7.9 \%$ & 9 & $8.9 \%$ & \multirow{7}{*}{0.329} & \multirow{7}{*}{0.05} \\
\hline & Everyday & 24 & $17.0 \%$ & 11 & $10.9 \%$ & & \\
\hline & Once a week & 63 & $45.0 \%$ & 47 & $46.5 \%$ & & \\
\hline & Twice a week & 21 & $15.0 \%$ & 18 & $17.8 \%$ & & \\
\hline & Fortnightly & 10 & $7.1 \%$ & 8 & $7.9 \%$ & & \\
\hline & Once in a month & 9 & $6.4 \%$ & 7 & $6.9 \%$ & & \\
\hline & Others & 2 & $1.4 \%$ & 1 & $0.99 \%$ & & \\
\hline
\end{tabular}

Source: Climate Change Survey 2015

Table: 4. Challenges of Waste Disposal Collection

\begin{tabular}{|c|c|c|c|c|c|c|c|}
\hline \multirow{2}{*}{ Question } & \multirow[b]{2}{*}{ Response Categories } & \multicolumn{2}{|c|}{ Urban } & \multicolumn{2}{|c|}{ Rural } & \multirow[t]{2}{*}{$\begin{array}{r}\text { Pearson } \\
\text { Chi } \\
\end{array}$} & \multirow[t]{2}{*}{$\begin{array}{l}\text { P- } \\
\text { Value }\end{array}$} \\
\hline & & No. & $\%$ & No. & $\%$ & & \\
\hline \multirow{8}{*}{$\begin{array}{l}\text { What is the } \\
\text { most } \\
\text { important } \\
\text { challenge } \\
\text { associated } \\
\text { with waste } \\
\text { collection in } \\
\text { your } \\
\text { community } \\
\text { ? }\end{array}$} & $\begin{array}{l}\text { Inability to afford fees charged by } \\
\text { government waste collectors }\end{array}$ & 19 & 13.6 & 11 & 10.9 & \multirow{8}{*}{0.612} & \multirow{8}{*}{0.05} \\
\hline & $\begin{array}{l}\text { Inability to afford fees charged by waste } \\
\text { collector firms }\end{array}$ & 22 & 15.7 & 15 & 14.9 & & \\
\hline & $\begin{array}{l}\text { Lack of government-designated waste } \\
\text { dumps/skips }\end{array}$ & 34 & 24.3 & 31 & 30.7 & & \\
\hline & $\begin{array}{l}\text { Ignorance of the people on the benefits of } \\
\text { good waste management behaviour }\end{array}$ & 39 & 27.9 & 28 & 27.7 & & \\
\hline & $\begin{array}{l}\text { Lack of space for sitting designated refuse } \\
\text { dumps due to the crowded nature of buildings }\end{array}$ & 17 & 12.1 & 13 & 12.9 & & \\
\hline & Nature of food items consumed by the people & 5 & 3.6 & 2 & 1.9 & & \\
\hline & $\begin{array}{l}\text { Nature of luxury items consumed by the } \\
\text { people }\end{array}$ & 0 & .0 & 0 & 0 & & \\
\hline & Others & 4 & 2.9 & 1 & 0.9 & & \\
\hline
\end{tabular}

Source: Climate Change Survey 2015 


\subsection{Renewable Energy}

The adaptation and switching to renewable energy to minimize the effect of climate change caused by carbon emissions and environmental pollution is pertinent and drawing the attention of world leaders. Thus information about the respondents "types of energy sources", knowledge on renewable energy and how much they are willing to pay for renewable energy are discussed in this subsection. Table 5 revealed the knowledge and usage of renewable energy by the sampled respondents. It shows that respondents in the urban area ranked hydroelectric source of renewable energy as the source they are more aware of compare to other sources. This followed closely by solar, wind, biomass and geothermal in that order. For the respondents in rural areas, solar was ranked higher than any of the sources. The hydroelectric source remains the major type of renewable energy that has been mostly used by the respondents (urban and rural). Sources like wind and geothermal have not been used by most of the respondents because they are not readily available to the respondents. From table 6, a larger percentage of urban and rural ( 88.3 and 74.4 per cent) respectively indicated that they would be able to pay if renewable energy tariff were introduced this indicates that the respondents have an idea about other sources of energy and are willing to reduce their carbon footprint to avoid the consequences of climate change. The result also shows that over 60 per cent of the respondents consider energy costs when building, buying or renting a house.

Table: 5 Urban and Rural knowledge of different sources of Renewable energy

\begin{tabular}{|c|c|c|c|c|c|c|c|}
\hline \multirow{2}{*}{ Question } & \multirow[b]{2}{*}{ Response Categories } & \multicolumn{2}{|c|}{ Urban } & \multicolumn{2}{|c|}{ Rural } & \multirow{2}{*}{$\begin{array}{r}\text { Pearso } \\
\text { n } \\
\text { Chi }\end{array}$} & \multirow[t]{2}{*}{$\begin{array}{r}\text { P- } \\
\text { Value }\end{array}$} \\
\hline & & $\begin{array}{c}\text { No } \\
\text {. }\end{array}$ & $\%$ & No & $\%$ & & \\
\hline \multirow{5}{*}{$\begin{array}{l}\text { Rank your } \\
\text { knowledge of the } \\
\text { following sources of } \\
\text { renewable energy. }\end{array}$} & Wind & 95 & $\begin{array}{r}65 . \\
5\end{array}$ & 24 & $\begin{array}{r}19 . \\
2\end{array}$ & \multirow{5}{*}{0.456} & \multirow{5}{*}{0.05} \\
\hline & Solar (sun) & $\begin{array}{r}13 \\
5\end{array}$ & $\begin{array}{r}93 . \\
1\end{array}$ & 91 & $\begin{array}{r}72 . \\
8\end{array}$ & & \\
\hline & $\begin{array}{l}\text { Biomass (the use of plant and animal } \\
\text { waste to create power) }\end{array}$ & 58 & 40 & 11 & 8.8 & & \\
\hline & $\begin{array}{l}\text { Geothermal (the use of heated water } \\
\text { and steam from the earth to produce } \\
\text { power) }\end{array}$ & 42 & $\begin{array}{r}28 . \\
9\end{array}$ & 9 & 7.2 & & \\
\hline & $\begin{array}{l}\text { Hydroelectric (the use of flowing water } \\
\text { to move turbines which generate } \\
\text { power) }\end{array}$ & $\begin{array}{r}14 \\
2\end{array}$ & $\begin{array}{r}97 . \\
9\end{array}$ & 83 & $\begin{array}{r}66 . \\
4\end{array}$ & & \\
\hline \multirow{5}{*}{$\begin{array}{l}\text { Which of the sources } \\
\text { of renewable energy } \\
\text { have you used } \\
\text { before? }\end{array}$} & Wind & 0 & 0 & 0 & 0 & \multirow{5}{*}{0.656} & \multirow{5}{*}{0.05} \\
\hline & Solar (sun) & 79 & $\begin{array}{r}54 . \\
5\end{array}$ & 37 & $\begin{array}{r}29 . \\
6\end{array}$ & & \\
\hline & $\begin{array}{l}\text { Biomass (the use of plant and animal } \\
\text { waste to create power) }\end{array}$ & 2 & 1.4 & 0 & 0 & & \\
\hline & $\begin{array}{l}\text { Geothermal (the use of heated water } \\
\text { and steam from the earth to produce } \\
\text { power) }\end{array}$ & 0 & 0 & 0 & 0 & & \\
\hline & $\begin{array}{l}\text { Hydroelectric (the use of flowing water } \\
\text { to move turbines which generate } \\
\text { power) }\end{array}$ & $\begin{array}{r}13 \\
9\end{array}$ & $\begin{array}{r}95 . \\
9\end{array}$ & 78 & $\begin{array}{r}62 . \\
4\end{array}$ & & \\
\hline
\end{tabular}

Source: Climate Change Survey 2015

Table 6. Urban and Rural Reactions to the cost of Renewable Energy

\begin{tabular}{|c|c|c|c|c|c|c|c|}
\hline \multirow[t]{2}{*}{ Questions } & \multirow[b]{2}{*}{ Response Categories } & \multicolumn{2}{|c|}{ Urban } & \multicolumn{2}{|c|}{ Rural } & \multirow[t]{2}{*}{ Pearson's Chi } & \multirow[t]{2}{*}{ P-Value } \\
\hline & & No. & $\%$ & No. & $\%$ & & \\
\hline \multirow{2}{*}{$\begin{array}{l}\text { Whether the respondents would } \\
\text { be able to pay, if renewable } \\
\text { energy tariff is introduced }\end{array}$} & Yes & 128 & 88.3 & 93 & 74.4 & 0.214 & 0.05 \\
\hline & No & 17 & 11.7 & 32 & 25.6 & & \\
\hline \multirow{3}{*}{$\begin{array}{l}\text { Did you take energy costs into } \\
\text { account when building, buying } \\
\text { or renting your place of } \\
\text { residence? }\end{array}$} & Yes & 98 & 67.6 & 78 & 62.4 & 0.835 & 0.05 \\
\hline & No & 34 & 23.4 & 27 & 21.6 & & \\
\hline & Don't know & 13 & 8.9 & 20 & 16.0 & & \\
\hline
\end{tabular}

Source: Climate Change Survey 2015 


\section{Conclusion and Policy Recommendation}

The purpose of this study is to generate information from the respondents about their knowledge and understanding of climate change risk and adaptation to renewable energy as a way of mitigating their carbon footprint. The results revealed respondents understanding and knowledge of climate change and renewable energy. Issues such as causes and effects of climate change, changes in rainfall and temperatures, and sources of their knowledge about climate change as well as the action they are prepared to take to mitigate their carbon footprint. The source of respondents' knowledge about climate change highlighted teaching from school as one of the major source this supported empirical findings that knowledge through education and information through awareness are the key issues that will help in militating against climate change. The findings of the study also revealed that the respondent considers energy cost when building, buying and renting a house. The striking feature of the results obtained is the level of willingness of the rural dwellers to pay any amount for renewable energy, the study, therefore, concludes that renewable energy should be introduced as an alternative source of energy at a minimal cost to address the issue like deforestation that can help to reduce carbon footprint as the main source of climate change. The study, therefore, recommends the following:

- Since respondents are willing to pay for renewable energy as an adaptation strategy, the issue of affordability and accessibility, which is a major problem, should be handled with utmost urgency.

- More awareness should be created about the causes, adaptation and mitigation strategy of climate change risk in Nigeria

- Establishment of a proper waste management system by private and public institutions should be encouraged since the study shows that waste disposal, energy consumption and transportation accounted for the greatest sources of GHGs in Nigeria.

- $\quad$ Private and Public Investment should be made in renewable energy as an alternative source of energy to mitigate against carbon footprint.

\section{References}

Brown, M. A., Southworth, F., and Sarzynski, A. (2011). Shrinking the Carbon Footprint of Metropolitan America. Brookings Institution Metropolitan Policy Programme.

Barr, S. (2007). Factors influencing environmental attitudes and behaviours: a UK case study of waste management Environment and Behaviour, 39, (4), 435-473.

Brauer, M., Joseph, F., Greg, F., and Aaron, V. (2015). “Ambient air pollution exposure estimation for the Global Burden of Disease 2013." Environmental Science and Technology. Jan 5;50 (1):79-88.

Boon, H. J. (2010). Climate Change? Who Knows? A comparison of Secondary School and Pre- Service Teacher" Australia Journal of Teachers Education, Vol 35, No. 1.

Bostrum, A. Morgan, M.C., Frischoff, B. and Real, D. (1994). What do people know about Global Climate Change? Mental Model 1. Risk Analysis. Vol 14, No 6.

Bob, M., Bruce, P. Catherine, C. and Rob. L (2010) Achieving Voluntary Reduction in the Carbon Footprint of Tourism and Climate Change. Journal of Sustainable Tourism, Vol 18, Issue 3.

Dave, A. (2009). Carbon Footprint of Various Sources of Heat - Biomass Combustion and CHPDH comes out lowest. Claverton Energy Research Group.

De Sousaa K., Casanovesd F, Sellaree J., Ospinad A., Suchinif J. G., Aguilarg A., Mercadoa L., (2018) "How climate awareness influences farmers' adaptation decisions in Central America?" Journal of Rural Studies 64 (2018) 11-19

Energy Commission of Nigeria (1998) World Solar Programme, 1996 - 2005”, Projects of the Government of Nigeria: Project Documents, ECN Abuja.

Eugene, C.C., Anne, M.T. and Diana A. (2008). Climate Change Education and Ecological Footprint. Selected Works San Jose State University.

Intergovernmental Panel on Climate Change IPCC (2007) Summary for Policy Makers. 'In S. Solomon, D.

Qin and M. Manning (eds), Climate Change 2007: The Physical Science Basis. Contribution of Working Group I to the Fourth Assessment Report of the Intergovernmental Panel on Climate

Change Intergovernmental Panel on Climate Change IPCC (2014) NASA- Global Climate Change Vital Signs for the Planet.

Jain P. C. (1993). "Greenhouse effect and climate change: scientific basis and overview" Renewable Energy Volume 3, Issues 4-5, June-July 1993, Pages 403-420

IPCC, (2007): Climate Change 2007: Mitigation. Contribution of Working Group III to the Fourth Assessment Report of the Intergovernmental Panel on Climate Change [B. Metz, O.R. Davidson, P.R.

Bosch, R. Dave, L.A. Meyer (eds)], Cambridge University Press, Cambridge, United Kingdom and New York, NY, USA., XXX pp.

Ihedioha, M. (2007) Climate Change: the impact and potential benefit for developing Nations. Journal of Agriculture Research and Review Pgs 002- 012. 
Mertz, O. Mbow, C., Reenberg, A., and Diouf, A. (2009). Farmers Perceptions of Climate Change and Agricultural Adaptation Structures in Rural Saheel. Environmental Management 43: 804- 816.

N. Ahmad, H.A.M. Shaffril, A.A. Samah, et al., The adaptation towards climate change impacts among islanders in Malaysia, Science of the Total Environment (2019), https://doi.org/10.1016/j.scitotenv.2019.134404

Onokerhoraye, A.G (1994). Human Geography for Africa The Benin Social Series for Africa, Benin City, Nigeria. Report of the Inter-Ministerial Committee on Combating Deforestation and Desertification, August 2000.

Ole, M., Cheikh, M., Anette, R and Awa, D (2009) "Farmers Perceptions of Climate Change and Agricultural Strategies in Rural Sahel. Journal of Environmental Management, 4(3) 804-816

Uyigue, E., and Agho, M (2007) "Coping with climate change and environmental. Degradation in the Niger delta of Southern Nigeria" Community Research and Development Center Benin City Nigeria.

Simbine A.T. Ogundele F., and Okuwa O.B. (2008). Climate Change and International Politics: Lessons for Nigeria; in Challenges of Climate Change for Nigeria a Multidisciplinary Perspective. Edited by Tunji Akande and Ajibola Kumuyi. NISER, Publication.

Shahid Z., Piracha A. (2016) Awareness of Climate Change Impacts and Adaptation at Local Level in Punjab, Pakistan. In: Maheshwari B., Singh V., Thoradeniya B. (eds) Balanced Urban Development: Options and Strategies for Liveable Cities. Water Science and Technology Library, Vol 72. Springer, Cham

Spiess, T. and De Sousa, C. (2016) "Barriers to Renewable Energy Development Brownfields" Journal of Environmental Policy and Planning. Taylor and Francis Online Publication.

Stephenson, J. Karen, Newman and Susannah, Mayhew (2014) "Population Dynamics and Climate Change: What are the links" Journal of Public Health Vol 32 No 2 pp 150-156.

Stephenson, J., Barton, B., Carrington, G., Gnoth, D., Lawson, R., and Thorsnes, P.(2010) "Energy culture A framework for understanding energy behaviours" Research Commons, University of Waikato.

Prasad, S. Ravi and Sud Ridhima (2018) "Implementing Climate Change Adaptation: Lessons from India's National adaptation from Climate Change (NAFCC)" Journal of Climate Policy. Vol 19, 2019 issue 3 Published Online August 2018. Taylor and Francis, Online Publication.

Wright, L., Kemp, S., and Williams, I. (2011) Carbon footprinting': towards a universally accepted definition". Carbon Management 2 (1): 61-72.

Weaver, A.A. (2002). Determinants of environmental attitudes: A five-country comparison. International journal of sociology, 32, (1), 77-108 